\title{
Seed Germination and Initial Growth of Quinoa Seedlings Under Water and Salt Stress
}

\author{
Geovana Facco Barbieri ${ }^{1}$, Raquel Stefanello ${ }^{1}$, Janine Farias Menegaes ${ }^{1}$, Janete Denardi Munareto \\ \& Ubirajara Russi Nunes ${ }^{1}$ \\ ${ }^{1}$ Federal University of Santa Maria, Rio Grande do Sul, Brazil \\ Correspondence: Geovana Facco Barbieri, Federal University of Santa Maria, Roraima Avanue, 1000, Camobi, \\ 97105900, Santa Maria, Rio Grande do Sul, Brazil. Tel: 55-996-486-609. E-mail: geovanafacco@hotmail.com
}

\author{
Received: May 20, 2019 Accepted: July 13, $2019 \quad$ Online Published: September 15, 2019 \\ doi:10.5539/jas.v11n15p153 URL: https://doi.org/10.5539/jas.v11n15p153
}

\begin{abstract}
Excessive amounts of salts and soil water deficiency interfere on seed germination and the full development of several crops. The objective of this research was to evaluate the effect of water stress and salinity on the germination process and initial growth of quinoa (Chenopodium quinoa Willd.) seedlings. In the first experiment, two quinoa seed lots with different physiological conditions were distributed on paper soaked in aqueous solution containing polyethylene glycol PEG-6000 in osmotic potentials corresponding to $0.0 ;-0.1 ;-0.2 ;-0.3$ and -0.4 MPa and held at $20^{\circ} \mathrm{C}$ under 8 hours of light exposition. In the second experiment, solutions of sodium chloride $(\mathrm{NaCl})$, potassium chloride $(\mathrm{KCl})$, calcium chloride $\left(\mathrm{CaCl}_{2}\right)$ and magnesium chloride $\left(\mathrm{MgCl}_{2}\right)$ were used to simulate the effect of salinity using the osmotic potentials, temperature and light conditions previously described. Assessed parameters were the germination percentage, first count, length and dry mass of seedlings. There was a reduction in quinoa germination percentage, first seed count and seedling length as the osmotic potential decreased in $\mathrm{CaCl}_{2}, \mathrm{NaCl}, \mathrm{KCl}, \mathrm{MgCl}_{2}$ and PEG-6000 solutions. The quinoa seeds exhibited higher tolerance to $\mathrm{NaCl}$ and $\mathrm{KCl}$ salts in the germination process and initial seedling growth. The progressive reduction of the osmotic potential induced by salts $\mathrm{NaCl}, \mathrm{KCl}, \mathrm{CaCl}_{2}, \mathrm{MgCl}_{2}$ and PEG-6000 negatively affects seed germination and initial growth of quinoa seedlings.
\end{abstract}

Keywords: Chenopodium quinoa Willd., germination process, salinity

\section{Introduction}

Quinoa (Chenopodium quinoa Willd.) belongs to the Amaranthaceae family and is native from the Andean region of South America, being recently introduced to Brazil in the 1990s (Ceccato, Berleto, \& Batlla, 2011). The crop exhibits high yield potential under adverse climatic and soil conditions. In addition, the grains present enhanced nutritional properties, arising as a complement in human and animal diets, besides being used as a forage and cover crop (Strenske, Vasconcelos, Egewarth, Herzog, \& Malavasi, 2017).

Seed germination is a critical stage in plant life cycle, depending on the genetics of each species and environmental conditions that seeds are exposed. In arid and semi-arid regions with recurrent adversities such as salinity and water deficiency, the water absorption by the seed during the germination process is hampered by the negativity of the soil matrix potential (Santos, N. V. Silva, Walter, E. C. A. Silva, \& Nogueira, 2016).

Excessive amounts of salts and soil water deficiency are abiotic factors that directly interfere on seed germination and full crop development, limiting the maximum yield performance (Torres, Vieira, \& Marcos Filho, 2000; Moterle, Lopes, Braccini, \& Scapim, 2006). In addition to the water absorption restriction due to the reduction of soil potential, toxic effects in seeds undergoing the germination process have been observed. These toxic effects may lead to cell metabolism alterations, reduction in germination percentage and speed, and changes in the development and growth of seedlings (Pelegrini, Borcioni, Nogueira, Koehler, \& Quoirin, 2013; Santos et al., 2016).

Movement of the water present in the solution through the seed tissues is necessary for the proper trigger of the seed germination process. This movement is dependent on the presence of a water potential gradient, which is reduced when there is presence of salts and eventually restricts seed water absorption (Pereira, C. C. Martins, D. Martins, \& Silva, 2014). Besides the negative interference caused by plant toxicity, the presence of salts in the 
solution, such as sodium chloride $(\mathrm{NaCl})$, calcium chloride $\left(\mathrm{CaCl}_{2}\right)$ and potassium chloride $(\mathrm{KCl})$ can act as an inducer of plant water stress (Souza \& Cardoso, 2000).

In this sense, evaluation of the germination process and seedling development under conditions of salinity and water deficiency are substantial since they may be related to crop sensitivity or tolerance at subsequent development stages (Taiz \& Zeiger, 2013). Thus, aiming to identify quinoa tolerance to cropping in saline or water deficient environments, the objective of this research was to evaluate the effect of water stress and salinity on the germination process and initial growth of quinoa seedlings.

\section{Material and Methods}

The research was carried out by means of two completely randomized design experiments during 2018 at the Didactic and Seed Research Laboratory, belonging to the Federal University of Santa Maria (UFSM).

\subsection{Water Stress}

For experiment 1, two lots of quinoa seeds of the Q 13-31 line were used to evaluate the water stress on the quinoa germination process. Seeds were obtained through cultivation in the Experimental Area of the Plant Science Department (UFSM) during the 2017 agricultural year. After the characterization of the seed lots, lot 1 was classified with germination of $86 \%$ and vigor of $83 \%$, while lot 2 exhibited germination of $70 \%$ and vigor of $64 \%$. Both lots exhibit minimum germination value required by MAPA (Ministry of Agriculture, Livestock and Supply) for the marketing as seed (> 60\%) (Brasil, 2011).

The water deficiency was simulated with aqueous solutions containing polyethylene glycol (PEG-6000) concentrations required to obtain osmotic potentials corresponding to $0.0 ;-0.1 ;-0.2 ;-0.3$ and $-0.4 \mathrm{MPa}$. The control treatment $(0.0 \mathrm{MPa})$ corresponded to the solution containing only distilled water. The amount of PEG-6000 required to obtain the different osmotic potentials was determined in Table 1 and was obtained from Villela et al. (1991).

Table 1. Amount of salts calcium chloride $\left(\mathrm{CaCl}_{2}\right)$, sodium chloride $(\mathrm{NaCl})$, potassium chloride $(\mathrm{KCl})$ and magnesium chloride $\left(\mathrm{MgCl}_{2}\right)$ and polyethylene glycol (PEG-6000) in $\mathrm{g} \mathrm{L}^{-1}$ to obtain solutions with different levels of osmotic potential

\begin{tabular}{llllll}
\hline \multirow{2}{*}{ Levels of osmotic potential (MPa) } & \multicolumn{5}{c}{ Salts $\left(\mathrm{g} \mathrm{L}^{-1}\right)$} \\
\cline { 2 - 5 } & $\mathrm{CaCl}_{2}$ & $\mathrm{NaCl}$ & $\mathrm{KCl}$ & $\mathrm{MgCl}_{2}$ & \multirow{2}{*}{ PEG-6000 $\left(\mathrm{g} \mathrm{L}^{-1}\right)$} \\
\hline 0 & 0.00 & 0.00 & 0.00 & 0.00 & 0.00 \\
-0.1 & 6.03 & 1.33 & 3.06 & 8.34 & 72.48 \\
-0.2 & 12.06 & 2.67 & 6.12 & 16.68 & 112.23 \\
-0.3 & 18.09 & 4.00 & 9.17 & 25.02 & 143.18 \\
-0.4 & 24.12 & 5.33 & 12.23 & 33.36 & 201.32 \\
\hline
\end{tabular}

\subsection{Salt Stress}

For experiment 2, quinoa seeds of the Q 13-31 line with germination of $90 \%$ and vigor of $86 \%$ were used to evaluate the effect of salinity on the quinoa germination process. Seeds were obtained by field cropping in the Experimental Area of the Plant Science Department (UFSM) during the 2017 agricultural year. The experiment was arranged in a 4x5 factorial scheme, being the first factor levels constituted of salts calcium chloride $\left(\mathrm{CaCl}_{2}\right)$, sodium chloride $(\mathrm{NaCl})$, potassium chloride $(\mathrm{KCl})$ and magnesium chloride $\left(\mathrm{MgCl}_{2}\right)$, and the second by the osmotic potentials corresponding to $0.0 ;-0.1 ;-0.2 ;-0.3 ;-0.4 \mathrm{MPa}$. The control treatment $(0.0 \mathrm{MPa})$ corresponded to the solution containing only distilled water. The salt concentration required to obtain the osmotic potentials was determined in Table 1 and was obtained by the Van't Hoff equation cited by Taiz and Zeiger (2013), as follows:

$$
\Psi \text { os }=- \text { RTC }
$$

where, Yos: osmotic potential (atm); R: ideal gas constant $\left(8.32 \mathrm{~J} \mathrm{~mol}^{-1} \mathrm{~K}^{-1}\right)$; $\mathrm{T}$ : temperature (K); C: concentration $\left(\mathrm{mol} \mathrm{L}^{-1}\right)$. The $\mathrm{NaCl}$ concentrations were calculated by means of the calibration curve established by Braccini et al. (1996).

For the evaluation of water and saline stress (experiments 1 and 2), the standard germination test (SGT) was carried out with 4 replicates of 100 seeds distributed in transparent plastic boxes (gerbox) on three sheets of germitest paper soaked with distilled water or solution corresponding to the experiment, in the proportion of 2.5 
times the dry paper weight. After sowing, plastic boxes were accommodated in the B.O.D. (Biological Oxygen Demand) germination incubator and maintained at a constant temperature of $20{ }^{\circ} \mathrm{C}$ under 8 hours of light exposure. The first and second seedling counts were performed at four and six days after the beginning of the test. Results were expressed as a percentage of normal seedlings (Brasil, 2009). Normal seedlings were considered those that presented more than $1.5 \mathrm{~cm}$ and well-developed shoot and root system.

Normal seedlings deployed to assess seedling length and dry mass were obtained by sowing four replicates of 20 seeds arranged in two rows on the upper third of the germination paper. The paper was soaked on distilled water or the solution corresponding to the experiment and submitted to the same conditions of the SGT. At four days after sowing, the length of shoot and primary root of ten normal seedlings of each replicate was measured by means of a millimeter ruler. Dry mass determination was performed by drying the plant material in a forced ventilation oven at $65 \pm 5^{\circ} \mathrm{C}$ for $48 \mathrm{~h}$ (Nakagawa, 1999) and weighing it in a digital scale $(0.001 \mathrm{~g})$.

Data obtained in the experiments and expressed as a percentage was transformed using arc-sine $\sqrt{\% / 100}$ and subjected to analysis of variance (ANOVA). When significant, means were compared using the Scott-Knott test for the qualitative factor and regression analysis was performed for the quantitative factors, with $5 \%$ error probability, using the statistical software SISVAR (Ferreira, 2011). The significant higher order model $\left(\mathrm{R}^{2}\right)$ was selected using the equation that best fitted the data.

\section{Results and Discussion}

\subsection{Water Stress}

There was no significant interaction between the factors lots and osmotic potentials (Table 2). Therefore, the factors acted independently on the variables germination, first count, shoot, root and total length of quinoa seedlings. Analyzing the simple effects of the factors, there was a significant difference $(p<0.05)$ between the lots and the osmotic potentials of the solution containing PEG-6000 (Table 2).

Table 2. Summary of the analysis of variance for the variables germination $(\mathrm{G})$, first count (FC), total length (TL), shoot length (SL), root length (RL) and dry mass (DM) of quinoa seedlings exposed to different concentrations of PEG-6000

\begin{tabular}{llllllll}
\hline \multirow{2}{*}{ Source of variation } & \multirow{2}{*}{ DF } & \multicolumn{5}{c}{ Mean square } \\
\cline { 3 - 7 } & & G & FC & TL & SL & RL & DM \\
\hline Lot & 1 & $2624.40^{*}$ & $2624.40^{*}$ & $22.72^{*}$ & $13.57^{*}$ & $1.14^{*}$ & 0.006 \\
Concentration & 4 & $1272.25^{*}$ & $2717.65^{*}$ & $14.75^{*}$ & $5.37^{*}$ & $2.90^{*}$ & 0.104 \\
Concentration*Lot & 4 & 69.65 & 108.15 & 0.59 & 0.75 & 0.03 & 0.046 \\
Residue & 30 & 89.60 & 104.60 & 0.54 & 0.30 & 0.07 & 0.065 \\
\hline CV $(\%)$ & - & 13.72 & 18.07 & 14.32 & 18.17 & 13.35 & 17.11 \\
\hline
\end{tabular}

Note. * Significant at $5 \%$ probability by the $\mathrm{F}$ test. $\mathrm{CV}=$ Coefficient of variation.

Analyzing the means of the lots, it was verified that lot 1 was superior to lot 2 in all analyzed variables, except for dry mass, which theren't was significance (Table 3). In the control treatment with absence of PEG-6000, seeds from lot 1 and 2 presented a germination of 86 and $70 \%$, with a significant decrease in the other concentrations of PEG-6000, reaching values respectively of 52 and $43 \%$ at the $-0.4 \mathrm{MPa}$ osmotic potential (Table 3). The vigor results obtained in the germination first count also indicated reduction of the percentage of normal seedlings with decreased water potential of the solution. 
Table 3. Mean results of the percentage of normal seedlings in the first and final count of the germination test, shoot, root and total length, and dry mass of quinoa seedlings subjected to four levels of osmotic potential in solution of PEG-6000

\begin{tabular}{|c|c|c|c|c|c|c|}
\hline \multirow{2}{*}{ Lot } & \multicolumn{5}{|c|}{ Osmotic Potential (MPa) } & \multirow{2}{*}{ Mean * } \\
\hline & 0.0 & -0.1 & -0.2 & -0.3 & -0.4 & \\
\hline \multicolumn{7}{|c|}{ Germination (\%) } \\
\hline Lot 1 & 86 & 85 & 82 & 82 & 52 & $77 \mathrm{~A}$ \\
\hline Lot 2 & 70 & 68 & 67 & 57 & 43 & $61 \mathrm{~B}$ \\
\hline $\mathrm{CV} \%$ & 13.72 & & & & & \\
\hline \multicolumn{7}{|c|}{ First count $(\%)$} \\
\hline Lot 1 & 83 & 74 & 70 & 68 & 30 & $65 \mathrm{~A}$ \\
\hline Lot 2 & 64 & 64 & 51 & 42 & 23 & $49 \mathrm{~B}$ \\
\hline $\mathrm{CV} \%$ & 18.07 & & & & & \\
\hline \multicolumn{7}{|c|}{ Shoot length $(\mathrm{cm})$} \\
\hline Lot 1 & 3.53 & 4.64 & 4.64 & 3.01 & 2.29 & $3.62 \mathrm{~A}$ \\
\hline Lot 2 & 2.94 & 3.28 & 2.55 & 1.86 & 1.67 & $2.46 \mathrm{~B}$ \\
\hline $\mathrm{CV} \%$ & 18.17 & & & & & \\
\hline \multicolumn{7}{|c|}{ Root lenght $(\mathrm{cm})$} \\
\hline Lot 1 & 3.03 & 2.68 & 2.22 & 2.00 & 1.46 & $2.28 \mathrm{~A}$ \\
\hline Lot 2 & 2.51 & 2.52 & 1.94 & 1.63 & 1.10 & $1.94 \mathrm{~B}$ \\
\hline $\mathrm{CV} \%$ & 13.35 & & & & & \\
\hline \multicolumn{7}{|c|}{ Total length $(\mathrm{cm})$} \\
\hline Lot 1 & 6.56 & 7.33 & 6.86 & 5.01 & 3.75 & $5.90 \mathrm{~A}$ \\
\hline Lot 2 & 5.45 & 5.80 & 4.48 & 3.49 & 2.76 & $4.39 \mathrm{~B}$ \\
\hline $\mathrm{CV} \%$ & 14.32 & & & & & \\
\hline \multicolumn{7}{|c|}{ Dry mass (mg) } \\
\hline Lot 1 & 1.38 & 1.50 & 1.63 & 1.45 & 1.45 & $1.48 \mathrm{~A}$ \\
\hline Lot 2 & 1.43 & 1.55 & 1.63 & 1.68 & 1.25 & $1.51 \mathrm{~A}$ \\
\hline $\mathrm{CV} \%$ & 17.11 & & & & & \\
\hline
\end{tabular}

Note. * Means followed by upper case letters in the same column do not differ among each other at $5 \%$ error probability by the Scott-Knott test.

The results of this study corroborate with the findings of Sousa et al. (2018), which observed that water stress reduced seed germination and vigor of Bidens subalternans $\mathrm{L}$. and the species did not tolerate osmotic potentials greater than -0.4 MPa. Moreover, Stefanello et al. (2018) concluded that thyme (Thymus vulgaris L.) seed germination and seedling performance were negatively affected under PEG-6000-induced water stress starting from -0.3 MPa.

Distinctive modes of assimilation of water stress are observed when plants are submitted to water scarcity conditions. As a stress response, there may be a decrease in seed metabolism, limited digestion of reserves and translocation of metabolized products, which can reduce germination percentage. There is a wide range of response variation between species, from very sensitive to more resistant ones (Gordin, Scalon, \& Masetto, 2015; Feng, Lindner, Robbins, \& Dinnenya, 2016).

Shoot, root and total length of quinoa seedlings decreased as the water potential of the substrate decreased in both lots (Figures 1C, 1D, and 1E). Total seedling length reduction from $6.56 \mathrm{~cm}(0.0 \mathrm{MPa})$ to $3.75 \mathrm{~cm}(-0.4$ $\mathrm{MPa}$ ) was found in lot 1 and from $5.45 \mathrm{~cm}(0.0 \mathrm{MPa})$ to $2.76 \mathrm{~cm}(-0.4 \mathrm{MPa})$ was observed in lot 2 (Table 3). On the other hand, the seedling dry mass was not influenced by the different osmotic potentials in the two studied lots (Figure 1D). 

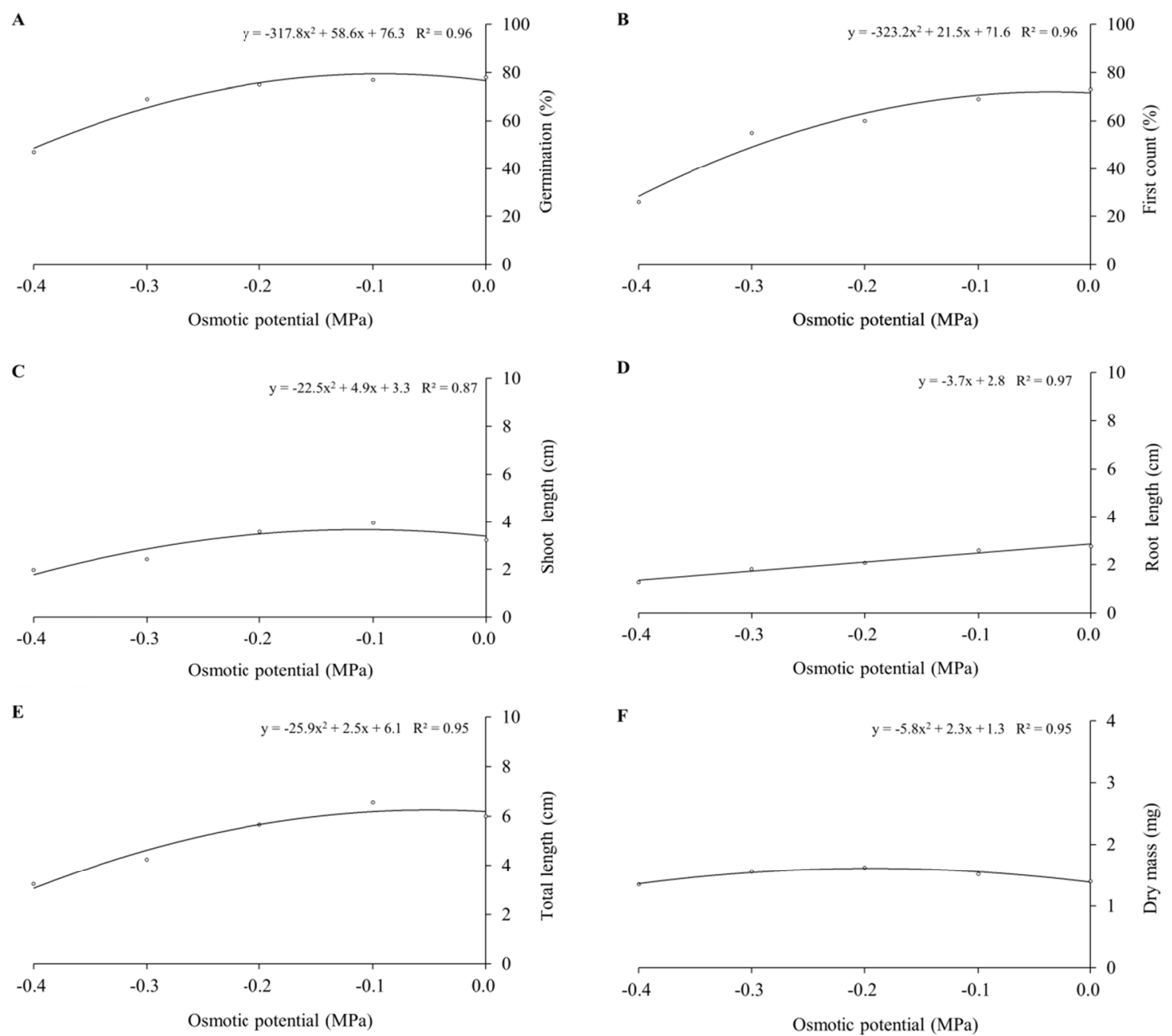

Figure 1. Germination percentage (A), germination first count (B), shoot length (C), root length (D) and total length (E), and seedling total dry mass (F) of quinoa seed subjected to four levels of osmotic potential in polyethylene glycol solution (PEG-6000)

Similar results to this study were obtained by Arcoverde et al. (2017), with decreased shoot length of niger (Guizotia abyssinica Cass.) as a function of decreased substrate water potential. Similarly, Hellal et al. (2018) found that the presence of increased PEG-6000 concentrations during growth of barley (Hordeum vulgare L.) seedlings inhibited developmental and survival traits, with decreased seedling vigor index occurring with increased stress levels.

\subsection{Salt Stress}

The analysis of variance evidenced interaction between the studied factors (salts and osmotic potentials) for the variables germination percentage, first count, root, shoot and total length, and dry mass of quinoa seedlings (Table 4). This result indicates that the osmotic potentials influenced the salt action on the seed germination process and initial growth of quinoa seedlings. 
Table 4. Summary of the analysis of variance for the variables germination (G), first count (FC), total length (TL), shoot length (SL), root length (RL) and dry mass (DM) of quinoa seedlings exposed to different concentrations of sais

\begin{tabular}{llllllll}
\hline \multirow{2}{*}{ Source of variation } & \multirow{2}{*}{$\mathrm{DF}$} & \multicolumn{5}{c}{ Mean square } \\
\cline { 3 - 7 } & & $\mathrm{G}$ & $\mathrm{FC}$ & $\mathrm{TL}$ & $\mathrm{SL}$ & $\mathrm{RL}$ & $\mathrm{DM}$ \\
\hline Sal & 3 & $5703.51^{*}$ & $6080.98^{*}$ & $41.24^{*}$ & $11.72^{*}$ & $12.28^{*}$ & $1.61^{*}$ \\
Concentration & 4 & $6626.92^{*}$ & $7778.42^{*}$ & $59.43^{*}$ & $6.97^{*}$ & $26.23^{*}$ & $1.82^{*}$ \\
Concentration*Salt & 12 & $793.22^{*}$ & $771.35^{*}$ & $3.47^{*}$ & $1.37^{*}$ & $0.94^{*}$ & $0.90^{*}$ \\
Residue & 60 & 30.75 & 37.78 & 0.52 & 0.13 & 0.12 & 0.04 \\
\hline CV $(\%)$ & - & 8.59 & 10.93 & 15.74 & 15.64 & 15.21 & 16.89 \\
\hline
\end{tabular}

Note. ${ }^{*}$ Significant at $5 \%$ probability by the $\mathrm{F}$ test. $\mathrm{CV}=$ Coefficient of variation.

For all salts, decreased germination percentage and vigor at the first count were observed as the osmotic potential of studied solutions became more negative (Figures $2 \mathrm{~A}$ and $2 \mathrm{~B}$ ). Nevertheless, $\mathrm{CaCl}_{2}$ and $\mathrm{MgCl}_{2}$ salts promoted greater negative interference in these variables when compared to $\mathrm{NaCl}$ and $\mathrm{KCl}$ salts, i.e., quinoa seeds presented greater tolerance to these salts in the germination process (Table 4). Different germination and first count results can be found due to chemical differences between the elements that constitute the solutions, even in similar osmotic potentials (Souza \& Cardoso, 2000).
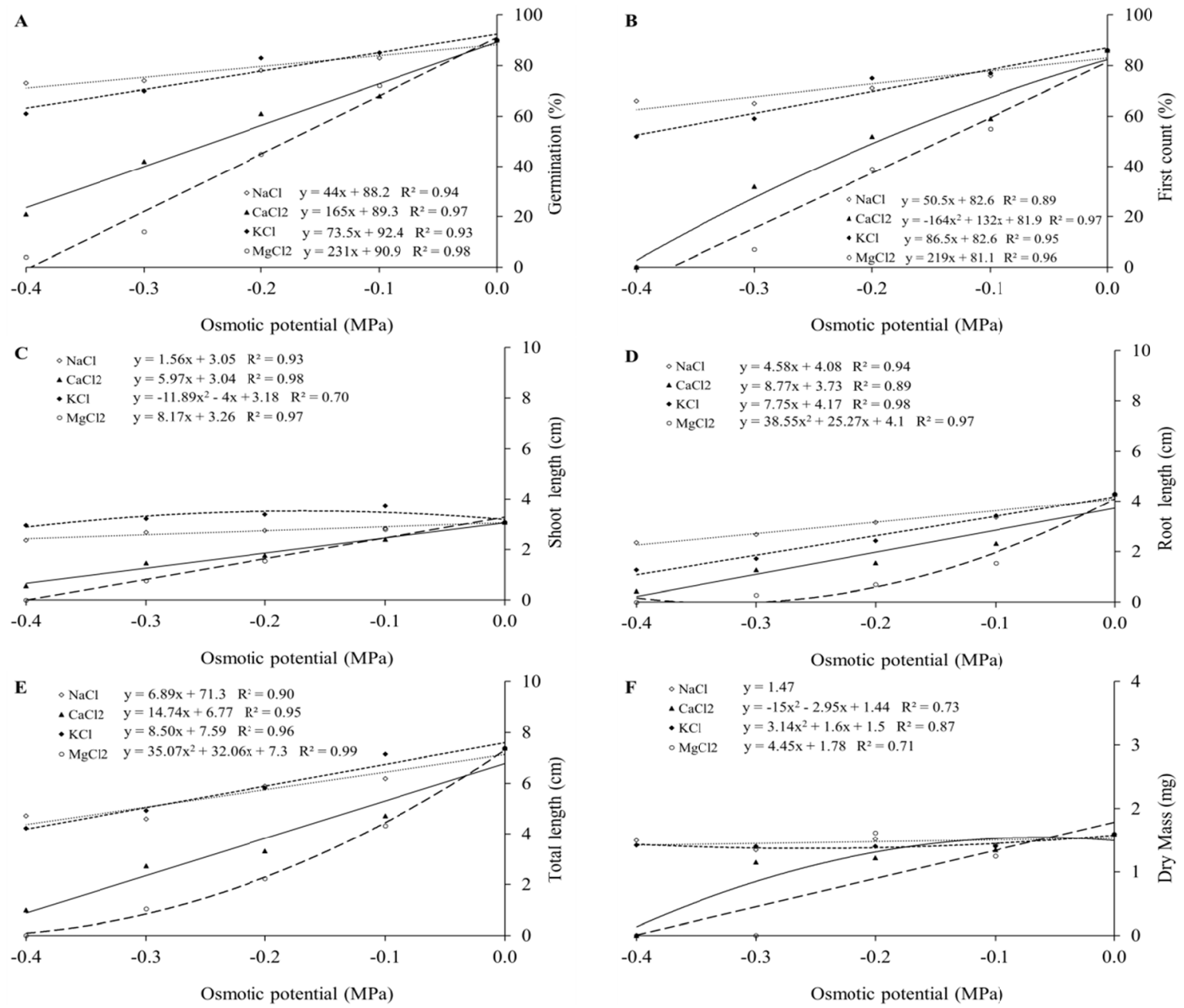

Figure 2. Germination percentage (A), germination first count (B), shoot length (C), root length (D) and total

length (E), and total dry mass of quinoa seedlings subjected to four levels of osmotic potential in calcium chloride solution $\left(\mathrm{CaCl}_{2}\right)$, sodium chloride $(\mathrm{NaCl})$, potassium chloride $(\mathrm{KCl})$ and magnesium chloride $\left(\mathrm{MgCl}_{2}\right)$ 
In the control treatment with absence of salts $(0.0 \mathrm{MPa}$ ), the seeds presented mean germination of $90 \%$ (Figure $2 \mathrm{~A}$ ). When subjected to the $\mathrm{NaCl}$ and $\mathrm{KCl}$ solutions, germination percentages greater than $80 \%$ were observed in the osmotic potentials of -0.1 and $-0.2 \mathrm{MPa}$, whereas germination percentages of 70 and $60 \%$ were observed in the solutions containing respectively the same salts in the osmotic potential of $-0.4 \mathrm{MPa}$ (Table 4). Nunes et al. (2009) and Bernardes et al. (2015) evaluated the effect of $\mathrm{NaCl}$ and $\mathrm{KCl}$ on germination of respectively sunn hemp (Crotalaria juncea L.) and cabbage (Brassica oleracea L. var. capitata) seeds and verified germination greater than $80 \%$ with salt solutions at the osmotic potential of $-0.2 \mathrm{MPa}$. Germination percentage was $80 \%$ when quinoa seeds were subjected to the $\mathrm{CaCl}_{2}$ and $\mathrm{MgCl}_{2}$ salts at the osmotic potential of $-0.1 \mathrm{MPa}$ and reached respectively 21 and $4 \%$ germination at the osmotic potential of $-0.4 \mathrm{MPa}$.

First count of quinoa seeds under saline solutions with $\mathrm{NaCl}$ and $\mathrm{KCl}$ displayed respectively 76 and $77 \%$ of normal seedlings at the osmotic potential of $-0.1 \mathrm{MPa}$ (Figure 2B). However, when the seeds were subjected to the same salts at the osmotic potential of $-0.4 \mathrm{MPa}$, there was a reduction respectively of 20 and 24 percentage points in the first count of normal seedlings in relation to the control treatment (absence of salts). Meanwhile, $32 \%$ and $7 \%$ of normal seedlings were recorded respectively with the solutions of $\mathrm{CaCl}_{2}$ and $\mathrm{MgCl}_{2}$ in the osmotic potential of $-0.3 \mathrm{MPa}$. Furthermore, null values of normal seedlings at the osmotic potential of $-0.4 \mathrm{MPa}$ were observed for both salts.

The shoot, root and total length were negatively affected by the salt treatments, being the most severe effect observed for $\mathrm{CaCl}_{2}$ and $\mathrm{MgCl}_{2}$ solutions in all osmotic potentials (Figures 2C, 2D, and 2E). The $\mathrm{MgCl}_{2}$ solution caused the greatest reduction in total length of quinoa seedlings at the maximum tested osmotic potential $(-0.4$ $\mathrm{MPa}$ ), promoting $100 \%$ inhibition of root and shoot growth of quinoa seedlings. Negative osmotic potentials obtained in saline solutions promote decreased seed vigor and can be evaluated by seedling length, which is negatively affected (Dickmann, Carvalho, Braga, \& Sousa, 2005).

In general, a more drastic effect of salt solutions was observed on the root length of quinoa seedlings when compared to the shoot length. In an investigation of the influence of saline solutions on the expression of the physiological quality of zucchini seeds (Cucurbita pepo L.), Harter et al. (2014) observed a decreasing linear effect for root and shoot length as the $\mathrm{NaCl}$ concentration increased, with the most pronounced effect on the seedling root portion, a similar result to those found in our research.

For shoot and root length, 2.4 and $2.4 \mathrm{~cm} ; 0.6$ and $0.4 \mathrm{~cm} ; 3.0$ and $1.3 \mathrm{~cm} ; 0.0$ and $0.0 \mathrm{~cm}$ were obtained respectively for the seedlings under solutions with $\mathrm{NaCl}, \mathrm{CaCl}_{2}, \mathrm{KCl}$ and $\mathrm{MgCl}_{2}$ at the maximum tested osmotic potential $(-0.4 \mathrm{MPa})$. Meanwhile, $3.1 \mathrm{~cm}$ of shoot and $4.3 \mathrm{~cm}$ of root length were found in the control solution $(0.0 \mathrm{MPa})$. The accumulation of ionic species in plant tissues, such as $\mathrm{Na}^{+}, \mathrm{Cl}^{-}, \mathrm{Mg}^{2+}$ and $\mathrm{Ca}^{2+}$, existing in the environment where root growth occurs can cause toxic effects to plants, affecting the absorption capacity, transport and use of ions required for their adequate growth (Nobre, Gheyi, Correia, Soares, \& Andrade, 2010).

In the treatment containing $\mathrm{MgCl}_{2}$ solution, there was a reduction in the dry mass of quinoa seedlings at the osmotic potential of $-0.1 \mathrm{MPa}$ in relation to the control and dry mass values equal to the control in the potential of $-0.2 \mathrm{MPa}$. In the osmotic potentials of -0.3 and $-0.4 \mathrm{MPa}$, the dry mass of quinoa seedlings was null. For $\mathrm{NaCl}$, $\mathrm{KCl}$ and $\mathrm{CaCl}_{2}$, smaller seedling dry mass values than the control were verified when under the different tested osmotic potentials.

Therefore, this generated informations aid to understand the effect of water stress and salinity of soils on the germination process and initial growth of quinoa seedlings, contributing with new knowledge about the physiology of this culture and as a way to indicate, in the future, this culture for cultivation in environments with these characteristics.

\section{Conclusion}

The progressive reduction of the osmotic potential induced by salts $\mathrm{NaCl}, \mathrm{KCl}, \mathrm{CaCl}_{2}, \mathrm{MgCl}_{2}$ and PEG-6000 negatively affects seed germination and initial growth of quinoa seedlings.

\section{References}

Arcoverde, S. N. S., Martins, E. A. S., Melo, R. M., Hartmann Filho, C. P., \& Gordin, C. R. B. (2017). Germinação e crescimento de plântulas de niger sob diferentes disponibilidades hídricas do substrato e regimes de luz. Revista Engenharia na Agricultura, 25(4), 344-353. https://doi.org/10.13083/reveng. v25i4.803

Bernardes, P. M., Mengarda, L. H. G., Lopes, J. C., Nogueira, M. U., \& Rodrigues, L. L. (2015). Qualidade fisiológica de sementes de repolho de alta e baixa viabilidade sob estresse salino. Nucleus, 12(1). https://doi.org/10.3738/1982.2278.1105 
Braccini, A. L., Ruiz, H. A., Braccini, M. C. L., \& Reis, M. S. (1996). Germinação e vigor de sementes de soja sob estresse hídrico induzido por soluções de cloreto de sódio, manitol e polietilenoglicol. Revista Brasileira de Sementes, 18(1), 10-16. https://doi.org/10.17801/0101-3122/rbs.v18n1p10-16

Brasil. (2009). Ministério da Agricultura, Pecuária e Abastecimento. Regras para análise de sementes. Secretaria de Defesa Agropecuária. Brasília: MAPA/ACS.

Brasil. (2011). Padrões de identidade e qualidade para a produção e a comercialização de sementes de espécies olerícolas, condimentares, medicinais e aromáticas. Portaria Secretaria de Defesa Agropecuária. Diário Oficial da União (№ 51 de 2 de Março de 2011, Seção I). Brasília, Brazil.

Ceccato, D. V., Bertero, H. D., \& Batlla, D. (2011). Environmental control of dormancy in quinoa (Chenopodium quinoa) seeds: Two potential genetic resources for pre-harvest sprouting tolerance. Seed Science Research, 21, 133-141. https://doi.org/10.1017/S096025851100002X

Dickmann, L., Carvalho, M. A. C., Braga, L. F., \& Sousa, M. P. (2005). Comportamento de sementes de girassol (Helianthus annuus L.) submetidas a estresse salino. Revista de Ciências Agro-Ambientais, 3, 64-75.

Feng, W., Lindner, H., Robbins, N. E., \& Dinnenya, J. R. (2016). Growing out of stress: The role of cell and organ-scale growth control in plant water-stress responses. The Plant Cell, 28, 1769-1782. https://doi.org/ $10.1105 /$ tpc. 16.00182

Ferreira, D. F. (2011). Sisvar: A computer statistical analysis system. Ciência e Agrotecnologia, 35(6), 1039-1042. https://doi.org/10.1590/S1413-70542011000600001

Gordin, C. R. B., Scalon, S. P. Q., \& Masetto, T. E. (2015). Disponibilidade hídrica do substrato e teor de água da semente na germinação de niger. Pesquisa Agropecuária Tropical, 45(3), 312-318. https://doi.org/ $10.1590 / 1983-40632015 \mathrm{v} 4535337$

Harter, L. S. H., Harter, F. S., Deuner, C., Meneghello, G. E., \& Villela, F. A. (2014). Salinidade e desempenho fisiológico de sementes e plântulas de mogango. Horticultura Brasileira, 32, 80-85. https://doi.org/ $10.1590 / \mathrm{S} 0102-05362014000100013$

Hellal, F. A., El-Shabrawi, H. M., Abd El-Hady, M., Khatab, I. A., El-Sayed, S. A. A., \& Abdelly, C. (2018). Influence of PEG induced drought stress on molecular and biochemical constituents and seedling growth of Egyptian barley cultivars. Journal of Genetic Engineering and Biotechnology, 16, 203-212. https://doi.org/ 10.1016/j.jgeb.2017.10.009

Moterle, L. M., Lopes, P. C., Braccini, A. L., \& Scapim, C. A. (2006). Germinação de sementes e crescimento de plântulas de cultivares de milho-pipoca submetidas ao estresse hídrico e salino. Revista Brasileira de Sementes, 28(3), 169-176. https://doi.org/10.1590/S0101-31222006000300024

Nakagawa, J. (1999). Testes de vigor baseados na avaliação das plântulas. In F. C. Krzyzanoswki, R. D. Vieira, \& J. B. França Neto (Eds.), Vigor de sementes: Conceitos e testes. Londrina: ABRATES.

Nobre, R. G., Gheyi, H. R., Correia, K. G., Soares, F. A. L., \& Andrade, L. O. (2010). Crescimento e floração do girassol sob estresse salino e adubação nitrogenada. Revista Ciência Agronômica, 41(3), 358-365. https://doi.org/10.1590/S1806-66902010000300006

Nunes, A. S., Lourenção, A. L. F., Pezarico, C. R., Scalon, S. P. Q., \& Gonçalves, M. C. (2009). Fontes e níveis de salinidade na germinação de sementes de Crotalaria juncea L. Ciência e Agrotecnologia, 33(3), 753-757. https://doi.org/10.1590/S1413-70542009000300013

Pelegrini, L. L., Borcioni, E., Nogueira, A. C., Koehler, H. S., \& Quoirin, M. G. G. (2013). Efeito do estresse hídrico simulado com NaCl, manitol e PEG (6000) na germinação de sementes de Erythrina falcata Benth. Ciência Florestal, 23(2), 511-519. https://doi.org/10.5902/198050989295

Pereira, M. R. R., Martins, C. C., Martins, D., \& Silva, R. J. N. (2014). Estresse hídrico induzido por soluções de PEG e de $\mathrm{NaCl}$ na germinação de sementes de nabiça e fedegoso. Bioscience Journal, 30(3), 687-696.

Santos, C. A., Silva, N. V., Walter, L. S., Silva, E. C. A., \& Nogueira, R. J. M. C. (2016). Germinação de sementes de duas espécies da caatinga sob déficit hídrico e salinidade. Pesquisa Florestal Brasileira, 36(87), 219- 224. https://doi.org/10.4336/2016.pfb.36.87.1017

Sousa, E. C., Matias, J. R., Pamplona, J. P., Carvalho, S. M. C., Mesquita, H. C., Oliveira, F. S., ... Torres, S. B. (2018). Water stress affect germination, seed vigor and seedlings growth of Bidens subalternans. Journal of Agricultural Science, 10(9), 326-332. https://doi.org/10.5539/jas.v10n9p326 
Souza, G. M., \& Cardoso, V. J. M. (2000). Effects of different environmental stress on seed germination. Seed Science and Technology, 28(3), 621-630.

Stefanello, R., Gaboardi, G. B., \& Neves, L. A. S. (2018). Estresse hídrico na germinação de sementes de tomilho (Thymus vulgaris Lamiaceae). Caderno de Pesquisa, 30(3), 13-20. https://doi.org/10.17058/ cp.v30i2.12220

Strenske, A., Vasconcelos, E. S., Egewarth, V. A., Herzog, N. F. M., \& Malavasi, M. M. (2017). Responses of quinoa (Chenopodium quinoa Willd.) seeds stored under different germination temperatures. Acta Scientiarum. Agronomy, 39(1), 83-88. https://doi.org/10.4025/actasciagron.v39i1.30989

Taiz, L., \& Zeiger, E. (2013). Fisiologia vegetal. Porto Alegre: Artimed.

Torres, S. B., Vieira, E. L., \& Marcos Filho, J. (2000). Efeitos da salinidade na germinação e no desenvolvimento de plântulas de pepino. Revista Brasileira de Sementes, 22(2), 39-43. https://doi.org/ 10.17801/0101-3122/rbs.v22n2p39-44

Villela, F. A., Doni Filho, L., \& Siqueira, E. L. (1991). Tabela de potencial osmótico em função da concentração de polietileno glicol 6000 e da temperatura. Pesquisa Agropecuária Brasileira, 26(11/12), 1957-1968.

\section{Copyrights}

Copyright for this article is retained by the author(s), with first publication rights granted to the journal.

This is an open-access article distributed under the terms and conditions of the Creative Commons Attribution license (http://creativecommons.org/licenses/by/4.0/). 